\title{
Integrated Sustainable Construction: A Course in Construction for Students in the U.S.A.
}

\begin{abstract}
The construction industry actively adopts the concept of sustainability to minimize the impact on the environment through accepting sustainable design and construction practices. This growing trend in sustainable construction requires both new knowledge and new skills for sustainability, in addition to conventional knowledge, such as scheduling, estimating, contracting etc. This is a paradigm change in the construction industry. Construction programs in the U.S.A should offer sustainable construction courses in order to teach sustainable knowledge and skills to their students before their entrance into industry.

The purpose of this study is to develop a sustainable construction course designed for university construction programs that uses a systematic course development approach which is divided into three stages. These include preparation, development, and improvement stages. During the preparation stage, the needs analysis is conducted in order to recognize and evaluate current sustainable construction courses offered by construction programs. In addition, in-depth literature review is performed to identify current trends in sustainable construction courses and related research. The development stage consists of: creating the framework for a sustainable construction course, choosing the goals and objectives for this course, choosing the contents of the course, organizing the chosen contents of the course, and planning the course schedule. At the improvement stage, the proposed course is improved, reviewed and evaluated by experts from both the construction industry and academia through an in-depth feedback process. From this systematically developed sustainable construction course, students in construction programs can learn basic knowledge of sustainability and the importance of sustainable design and construction. They will be exposed to different sustainable building rating systems such as Leadership in Energy and Environmental Design (LEED), collaborative skills among construction participants and the advantages and pitfalls of sustainable construction. In addition, these sustainable construction professionals will change the nature of the construction industry and society to help secure our earth.
\end{abstract}

\section{Introduction}

Construction is a significant industry that profoundly influences our economy, natural environment, health, and productivity. The construction industry in the U.S.A. employed over 6.7 million people in 732,000 companies and generated annual revenue over $\$ 1.1$ trillion in 2005 [1]. At the same time, the industry contributes to major environmental problems including global warming, climate change, ozone depletion, soil erosion, desertification, deforestation, acidification, loss of biodiversity, land pollution, water pollution, air pollution, and depletion of fisheries [2]. Moreover, the construction industry, especially the sectors of that industry devoted to buildings, develops products that strongly affect human health and comfort, productivity and overall quality of life [3]. With the recognition of these challenges and issues associated with construction activities, the building industry has accepted the concept of sustainability through sustainable construction. Sustainable construction indicates that buildings are designed, constructed, operated, and demolished in an environmentally and energy efficient manner which 
can reduce the impact of buildings on the environment, to improve working environments for building occupants, and reduce building operation and maintenance costs [4]. This sustainability movement with associated benefits not only has changed construction processes but also has created needs for sustainable construction education to construction participants in the various aspects of sustainable construction.

Construction programs have a vital role in sustainability education for their graduates because they produce many members of the construction workforce who will be leaders and change agents in the future. Several scholars have mentioned the importance of sustainable construction education in construction programs in several countries such as the U.K., the U.S.A., and Australia [11]. Major topics of sustainable construction follow: the current status of sustainable construction education; needs of sustainable construction education in construction programs including civil engineering programs; sustainable construction course case study for a specific program in Australia, and the needs of integration between existing construction courses and the concept of sustainability in construction curriculum. However, the previous studies, especially in the U.S.A., did not observe significant change within the construction curriculum, which would be integrated conventional courses in the areas of scheduling, estimating, contracting and sustainable knowledge and skills.

The purpose of this study is to develop a sustainable construction course designed for university construction programs that uses a systematic course development approach which is divided into three stages. These include the preparation, development, and improvement stages which is a procedure of systematic curriculum development [5].

During the preparation stage, the needs analysis is conducted in order to recognize and evaluate current sustainable construction courses offered by construction programs. In addition, an indepth literature review is performed to identify current trends in sustainable construction courses and related research. The development stage consists of creating the framework for a sustainable construction course; choosing the goals and objectives for this course; choosing the contents of the course; organizing the chosen contents of the course; and planning the course schedule. At the improvement stage, the proposed course is improved, reviewed and evaluated by experts from both the construction industry and academia through an in-depth feedback process.

From this systematically developed sustainable construction course, students in construction programs can learn basic knowledge of sustainability and the importance of sustainable design and construction. They will be exposed to different sustainable building rating systems such as Leadership in Energy and Environmental Design (LEED), collaborative skills among construction participants, and the advantages and pitfalls of sustainable construction. In addition, these sustainable construction professionals will change the nature of the construction industry and society to help secure our earth.

\section{Objective / Mission Statement}

The goal of this research is to develop a sustainable construction course for undergraduate students in construction education using the systematic approach. To accomplish the goal of this research, three research stages and fourteen specific objectives are created. 


\section{Phase I: Preparation}

At the preparation stage, this process strives to

- Search for recent research on sustainable design \& construction that includes similar names such as sustainable development and green building

- Perform literature reviews of course or course development processes

- Perform literature reviews about sustainability in construction education

- Perform literature reviews about construction education in general

- Perform background research of other sustainable construction courses and initiatives provided by other construction schools

\section{Phase II: Development}

The development stage of the process strives to

- Construct an overview/framework of 'sustainable construction for undergraduate students'

- Set the goals and objectives for the course

- Develop the contents and activities for the course

- Develop the instructional strategies for the learning topic

- Plan the evaluation and assessment instruments for the course

- Create the syllabus for the course and the course draft for the sustainable construction class

\section{Phase III: Improvement}

At the improvement stage, the process strives to

- Receive advice and evaluation from construction industry experts, construction education professors, and sustainable construction experts (LEED Accredited Professionals)

- Modify and make corrections to the course draft

- Document the outcomes of the process through publication

\section{Research Methodology}

\section{Research Scope and Procedure}

The sustainable construction course from this research is designed for the undergraduate students in construction programs. This course is the fundamental course for sustainable construction performed for one semester. It is beneficial for the undergraduate construction major students preparing for a future as construction leaders or innovators in the construction industry. Suggested prerequisite subjects for this course include materials, construction, scheduling, estimating and others. These subjects are not mandatory, but are recommended for improving student's comprehensive understanding and application.

In the contents of the course, there are several components in the course draft. First, the overview or framework will be created in order to provide a comprehensive context. It should include the course descriptions and plan of study for "Sustainable Construction". Second, the syllabus for the sustainable construction course will be created for the specific considerations such as the target, goal, objectives, contents/activities, assessment planning, and others. 
Setting up the course development procedure is essential in order to generate efficient and meaningful outcomes. According to Randolph and Posner [6], it necessary to set ten rules for planning successful research. In accordance with their rules, the initial step for the research is to set a clear project goal and objective. After that, researchers establish checkpoints at each milestone, activities, relationships, and time estimates.

\section{Research Methodology}

Course development using the systematic approach is the objective of this research. For more systematic research, the researchers set the stages of the course development through the literature reviews on systematic development theories. Just as "systematic course development" is also called the "objective model" in course theory, so the most important point in this theory is the establishment of objectives or goals [7].

The course development is divided into three major steps including preparation, development, and improvement. The research reviews the systematic curriculum theories and considerations and follows objectives-based research [5].

\section{Literature Review}

Literature reviews are performed in the initial part of this research. The literature review is divided into two main categories: systematic curriculum theories, and sustainable construction education.

Table 1. Literature Lists on the Curriculum Development Theories

\begin{tabular}{|c|l|}
\hline Number & Related Literatures \\
\hline 1 & Tyler, R. W., 1949. Basic principles of curriculum and instruction \\
\hline 2 & $\begin{array}{l}\text { Finch, C. R., Crunkilton, J. R., 1989. Curriculum Development in Vocational } \\
\text { and Technical Education; Planning, Content, Implementation. Allyn and } \\
\text { Bacon, INC. }\end{array}$ \\
\hline 3 & $\begin{array}{l}\text { Kwon, H. S., Yi, S. B., 2003. The development of hands-on activities based } \\
\text { production technology curriculum by objective model at the secondary school }\end{array}$ \\
\hline
\end{tabular}

The first category of literature, systematic curriculum development theories, is summarized in Table 1. Curriculum development focuses primarily on content and areas associated with it. However, the curriculum should define the educational goals and mission for the time being during the development procedure. Tyler [7] supported this idea, providing the four development procedures of setting educational goals, choosing educational experiences, organizing education experiences, and evaluating. In his curriculum development model, setting educational goals was the first initiation for curriculum development process. Also, Finch \& Crunkilton [8] supported this idea that curriculum developers should concentrate on setting their intended goals before the next developmental stage. Kwon \& Yi [9] employed a systematic curriculum development for secondary school manufacturing and construction technology program. Their development 
process was performed by four stages; constructing curriculum framework, setting educational goals, choosing content, and organizing content.

Table 2. Literature List on the Sustainable Construction Education

\begin{tabular}{|c|l|}
\hline Number & Related Literatures \\
\hline 1 & $\begin{array}{l}\text { Graham, P., 2000 Building education for the next industrial revolution: } \\
\text { teaching and learning environmental literacy for the building professions }\end{array}$ \\
\hline 2 & $\begin{array}{l}\text { Mead, S. P., 2002 Green building: Current status and implication for } \\
\text { construction education }\end{array}$ \\
\hline 3 & Tinker, A., Burt, R., 2004 “Greening" the Construction Curriculum \\
\hline 4 & $\begin{array}{l}\text { Cotgrave, A. and Alkhaddar, R., 2006 Greening the curricula within } \\
\text { construction programs }\end{array}$ \\
\hline 5 & Woodruff, P. H., 2006 Educating engineers to create a sustainable future \\
\hline 6 & $\begin{array}{l}\text { Hayles, C. S., Robson, K. and Holdsworth, S., 2006 A case study from RMIT: } \\
\text { Introducing property undergraduates to the immediate issues of housing } \\
\text { sustainability and affordability within Australia and New Zealand }\end{array}$ \\
\hline 7 & Hayles, C. and Holdsworth, S. E., 2006 Curriculum change for sustainability \\
\hline 8 & $\begin{array}{l}\text { Chau, K. W., 2007 Incorporation of sustainability concepts into a civil } \\
\text { engineering curriculum }\end{array}$ \\
\hline 9 & $\begin{array}{l}\text { Murray, P. E. and Cotgrave, A. J., 2007 Sustainability literacy: the future } \\
\text { paradigm for construction education }\end{array}$ \\
\hline
\end{tabular}

The second category of literature, sustainable construction education, is summarized in Table 2. Many journal and conference articles discuss the importance of sustainable construction education in construction programs worldwide. Graham [10] explained resource efficient design and construction called "sustainable building" and proposed the importance of teaching and learning environmental literacy for the building professions to achieve sustainable building. Mead [11] defined the status of sustainable construction in the construction industry and suggested the importance of sustainable construction education in construction programs. Woodruff [12] surveyed the familiarity of the concept of sustainability from environmental engineering faculties and environmental professionals as representatives of recent graduates to compare their opinion of sustainability education. Cotgrave \& Alkhaddar [13] developed sustainable curricula within construction programs in U.K. Chau [14] addressed the rationale behind the recent integration of sustainability concepts into a underrated civil engineering curriculum in Hong Kong.

Tinker and Burt [15] identified sustainability related courses in construction programs in the U.S.A. and explained the content of sustainable courses and the integration into the existing construction curriculum. Hayles \& Holdsworth [16] explained a number of initiatives to promote sustainability with the teaching of built environment disciplines at RMIT University Australia. In addition, Hayles, Robson \& Holdsworth [17] described a new approach to teaching sustainability to undergraduate construction students at RMIT University in Australia. Murray and Cotgrave [18] demonstrated the rationale for systematically embedding sustainability within the construction curriculum to the benefit of professionals, professional bodies and educators. From 
the literature review, the geographic context for these last studies indicates that leading institutions of sustainability education are located in the U.S.A., Australia, and the UK.

\section{Systematic Development for Sustainable Construction Course}

\section{Preparation Stage of Course Development}

Course development should be systematic because it provides the objective perspective or rationale in course development. The most interesting concern in the systematic approach to course development is the way a course maximizes its educational achievements. This systematic approach has been recognized as a classic in course development [7]. The systematic approach in the course development begins with the establishment of the goals and objectives. Choi [19] and Kwon and Yi [9] stress the development procedure in course development to include 'conceptualization, statement of objective, decision of contents, and organization work on contents, instructional strategies, and assessment planning'. In the systematic approach, the statement of the goal is an important starting point for course development. The preparation stage for course development is composed of the literature reviews in the areas of sustainable construction, course development theories, the current status of sustainable construction, and the status of sustainable construction education.

\section{Development Stage for Course Development}

In the development stage for course development, there were five sub-stages. At first, the basic framework for the sustainable construction course gave an outline or introduction of the course. Second, learning goals and objectives were set by reviewing other sustainable construction courses, research papers on sustainable construction, and construction industry interests. Third, learning topics were chosen by considering their relevance to the learning goals and objectives. With the systematic approach in mind, learning topics based on the learning goals and objectives were set. Fourth, instructional strategies and assessment plans were organized by pedagogical perspective. Considering the implementation of the learning topics in classroom, the research team concentrated on matching the learning topics with the appropriate instructional strategies. Finally, a final course syllabus was completed with the semester schedule plan (15 week plan).

\section{A Framework for Sustainable Construction Course}

At this step in the development stage, the course description and course framework for 'sustainable construction course' were developed to follow the systematic course development procedure as shown in Table 3 and Figure 1. These data are from deliberated considerations and needs of sustainable education and research papers on sustainable education.

\section{Table 3. Course Description for Sustainable Construction}

\begin{tabular}{|l|l|}
\hline Course Name & Sustainable Construction \\
\hline Target & Undergraduate Students in Construction Program \\
\hline Requirement & $\begin{array}{r}\text { Required over } 24 \text { credits: English I \& II, Calculus I \& II, } \\
\text { Economics, Physics I\&II (University Core Curriculum) }\end{array}$ \\
\hline
\end{tabular}




\begin{tabular}{|c|c|}
\hline & $\begin{array}{l}\text { 2. Fundamental construction courses required: estimating, } \\
\text { scheduling, contracting, building science, etc. } \\
\text { 3. Senior Students }\end{array}$ \\
\hline $\begin{array}{l}\text { Course } \\
\text { Description }\end{array}$ & $\begin{array}{l}\text { 'Sustainable construction' is a course to teach sustainability in built } \\
\text { environment to undergraduate students in a construction school. This } \\
\text { course will encourage students to comprehend the basic knowledge in the } \\
\text { sustainability in built environment, the importance of sustainability in } \\
\text { construction, and several sustainable rating systems in the industry such } \\
\text { as LEED, Earth Craft, etc. and to integrate the concepts of sustainability } \\
\text { into other construction knowledge. In addition, it enables them to get } \\
\text { interests for sustainability of their daily life and their career. Through a } \\
\text { variety of activities related to sustainable construction, they can be more } \\
\text { familiar with sustainable features; apply this knowledge to actual } \\
\text { construction while working at the construction field, and translate } \\
\text { consideration for the health of our earth to our next generation. }\end{array}$ \\
\hline $\begin{array}{l}\text { Major } \\
\text { Construction } \\
\& \\
\text { Considerations }\end{array}$ & $\begin{array}{l}\text { 1. Systematic approach in developing or designing the course } \\
\text { - Curriculum development theory } \\
\text { - The trends or needs of current construction education } \\
\text { 2. Process-based curriculum (Activities based learning) } \\
\text { 3. Case-based curriculum } \\
\text { 4. Learner-centered instruction } \\
\text { 5. Collaborative learning and continuous feedback }\end{array}$ \\
\hline
\end{tabular}

Figure 1. Framework for Sustainable Construction Course in Construction Education

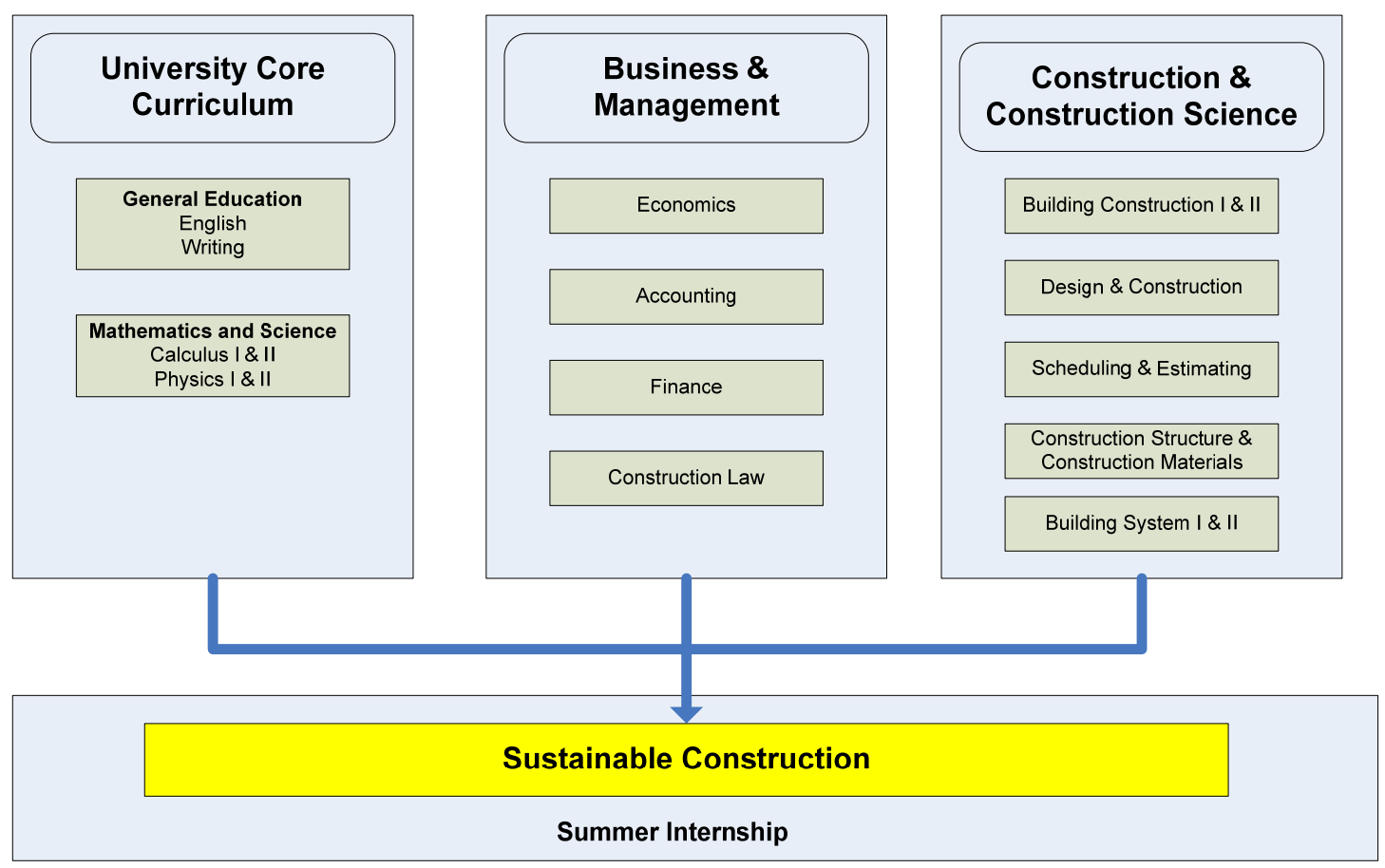




\section{Setting Learning Goals}

Setting learning goals is one of the most important procedures in the systematic course development. The first step in setting up learning goals of sustainable construction course in construction program is to study other sustainable construction related courses which are offered by other universities in the U.S.A., summarized in Table 4.Two methodologies were applied for finding sustainable construction related courses which were literature review and curriculum requirements for undergraduate construction courses. The syllabi were obtained by two ways which were downloaded from institution's website or instructor's personal websites if they were downloadable or were requested from instructors with research purpose. From the collected syllabi, the authors summarized courses' objectives.

Table 4. Sustainable Courses Offered in U.S.A.

\begin{tabular}{|c|c|}
\hline Course Name & $\begin{array}{l}\text { Purpose of Course } \\
\end{array}$ \\
\hline $\begin{array}{l}\text { Sustainable Building } \\
\text { Methods } \\
\text { (Penn State) }\end{array}$ & $\begin{array}{l}\text { This course introduces students to concepts of sustainability and green } \\
\text { design as applied in building construction. The goal of this course is to } \\
\text { help students develop the vocabulary and skills to become productive } \\
\text { contributors to sustainable building project teams. }\end{array}$ \\
\hline $\begin{array}{l}\text { Design-Build Montana: } \\
\text { Sustainable American Indian } \\
\text { Housing Solutions: An } \\
\text { Interdisciplinary Service } \\
\text { Learning Course } \\
\text { (Penn State) }\end{array}$ & $\begin{array}{l}\text { This course provides an interdisciplinary and hands-on experience in the } \\
\text { application of a sustainable building technologies and community-built } \\
\text { construction methods through a culturally diverse community partnership } \\
\text { with the Northern Cheyenne Indian tribe. }\end{array}$ \\
\hline $\begin{array}{l}\text { High-Performance Green } \\
\text { Building Delivery Systems } \\
\text { (University of Florida) }\end{array}$ & $\begin{array}{l}\text { The purpose of the course is provide an overview of emerging delivery } \\
\text { systems for high performance green buildings and the basis on which their } \\
\text { sustainability can be evaluated. The U.S. Green Building Council } \\
\text { Leadership in Energy and Environmental Design (LEED) criteria are } \\
\text { discussed in detail. }\end{array}$ \\
\hline $\begin{array}{l}\text { Sustainable Practice-Design } \\
\text { and Construction } \\
\text { (Colorado State Uni.) }\end{array}$ & $\begin{array}{l}\text { The course will focus on the major components of sustainable design and } \\
\text { construction, including energy, healthy buildings, cultural, natural } \\
\text { resource use and other environmental and economic issues of sustainable } \\
\text { built environments. }\end{array}$ \\
\hline $\begin{array}{l}\text { Sustainable Construction } \\
\text { (Texas A \& M Uni.) }\end{array}$ & $\begin{array}{l}\text { This course contributes sustainable construction methods and materials to } \\
\text { meet present and future needs. The goal of this course is to help identify } \\
\text { and analyze international, national and local programs promoting } \\
\text { sustainable construction. In addition students can learn characterization of } \\
\text { components in successful sustainable construction projects. }\end{array}$ \\
\hline $\begin{array}{l}\text { Sustainable Construction } \\
\text { (Southern Polytechnic State } \\
\text { University) }\end{array}$ & $\begin{array}{l}\text { The purpose of this course includes LEED certification techniques for } \\
\text { sustainable sites, water efficiency, energy \& atmosphere, materials \& } \\
\text { resources, indoor environmental quality, innovation and design. From the } \\
\text { course, the student will study and analyze how management and LEED } \\
\text { techniques are applied to current construction projects. }\end{array}$ \\
\hline $\begin{array}{l}\text { Sustainability } \\
\text { (Carnegie Mellon University) }\end{array}$ & $\begin{array}{l}\text { This course begins with an overview of the concept of sustainability and } \\
\text { its history, including changing attitudes and values toward technology and } \\
\text { the environment through the twentieth century. }\end{array}$ \\
\hline $\begin{array}{l}\text { Sustainable Case Studies } \\
\text { (Carnegie Mellon University) }\end{array}$ & $\begin{array}{l}\text { This course teaches the principles and tools of sustainability which have } \\
\text { yet to be applied on a large scale to solving real-world engineering } \\
\text { problems. In this course, we explore the use of these principles and tools } \\
\text { to various case studies. }\end{array}$ \\
\hline
\end{tabular}




\begin{tabular}{|l|l|}
\hline & $\begin{array}{l}\text { This course provides a introduction to means, methods, and analytical } \\
\text { practices associated with sustainability in the built environment, including } \\
\text { an overview f best practices for sustainable projects in the areas of } \\
\text { planning/development, site design, project management, energy and water } \\
\text { conservation and efficiency, green building materials, and indoor } \\
\text { environmental quality. Analytical methods include green building } \\
\text { (Virginia Tech) }\end{array}$ \\
$\begin{array}{l}\text { assessment tools and methods; Leadership in Energy and Environmental } \\
\text { Design (LEED) rating system; economic analysis of green building } \\
\text { alternatives; and evaluation for innovation and organizational change. }\end{array}$ \\
\hline
\end{tabular}

The setting of a learning goal of the 'Sustainable Construction' course has to consider industry expectations of the course because the acquired knowledge of sustainability will be applied to actual construction. According to Ahn \& Pearce [20], requested sustainable knowledge from industry for graduates in construction programs was ranked in the following order:

- General knowledge of sustainability in built environment

a. Sustainable building familiarity

b. Basic green knowledge

c. A general knowledge of the process

d. In-depth instruction with principals and design application

- Sustainable rating system and design of sustainability
a. LEED requirements
b. LEED certification course
c. Economic feasibility for LEED
d. Exposure to LEED
e. Accredited LEED student

- Sustainable construction material and methods

a. Construction materials and sustainable methods of construction alternative energy

b. Coordination of sustainable efforts with all parties at design phase such as HVAC items

c. Practical system for building that saved energy study ASHRAE 90.1

- Environmental philosophy

From the literature review and sustainable related course goals offered by universities, five learning goals and eighteen objectives were created for the 'Sustainable Construction course in construction program' as shown in Table 6. The descriptions of learning goals and objectives are originated from the pedagogical background of Bloom's taxonomy[21] that consists of the cognitive domain, affective domain, and psychomotor domain.

Table 5. Learning Goals and Objectives for Sustainable Construction Course

\begin{tabular}{|l|c|c|}
\hline \multicolumn{1}{|c|}{ Learning Goals } & \multicolumn{1}{|c|}{ Learning Objectives } & Type \\
\hline $\begin{array}{l}\text { 1. Understand the } \\
\text { general knowledge } \\
\text { of sustainability }\end{array}$ & $\begin{array}{l}\text { 1.1 Identify the definition and concept of } \\
\text { sustainability } \\
1.2 \begin{array}{l}\text { Understand the importance of environmental } \\
\text { philosophy } \\
1.3 \text { Understand the history of sustainability }\end{array}\end{array}$ & Cognitive \\
& Cognitive \\
\hline
\end{tabular}




\begin{tabular}{|c|c|c|}
\hline & 1.4 Describe terminology of sustainability & Cognitive \\
\hline $\begin{array}{l}\text { 2. Comprehend the } \\
\text { concept of } \\
\text { sustainability as } \\
\text { applied in } \\
\text { construction. }\end{array}$ & $\begin{array}{l}\text { 2.1 Identify sustainable construction practice in the } \\
\text { construction industry } \\
\text { 2.2 Understand why sustainable construction is } \\
\text { important in construction } \\
\text { 2.3 Analyze the pros and cons of sustainable } \\
\text { construction } \\
\text { 2.4 Identify sustainable alternatives to conventional } \\
\text { construction practices }\end{array}$ & $\begin{array}{l}\text { Cognitive } \\
\text { Cognitive } \\
\text { Cognitive } \\
\text { Cognitive }\end{array}$ \\
\hline $\begin{array}{l}\text { 3. Understand and } \\
\text { practice sustainable } \\
\text { construction } \\
\text { methods and } \\
\text { materials }\end{array}$ & $\begin{array}{l}\text { 3.1 Identify sustainable materials } \\
\text { 3.2 Perform a basic sustainable construction practice } \\
\text { to community } \\
\text { 3.3 Appreciate the importance of collaborative and } \\
\text { safe work } \\
\text { 3.4 Articulate feelings on working together } \\
\text { 3.5 Analyze the difference between theory and } \\
\text { actual practice } \\
\text { 3.6 Be proficient with communication work } \\
\text { 3.7 Perform the strategies of communication and } \\
\text { collaboration in a project }\end{array}$ & $\begin{array}{c}\text { Cognitive } \\
\text { Psychomotor } \\
\text { Cognitive } \\
\text { Affective } \\
\text { Cognitive } \\
\text { Affective } \\
\text { Psychomotor }\end{array}$ \\
\hline $\begin{array}{l}\text { 4. Being familiar with } \\
\text { sustainability rating } \\
\text { systems }\end{array}$ & $\begin{array}{l}\text { 4.1 Be able to apply sustainable rating systems such } \\
\text { as LEED, Earth Craft, etc. } \\
\text { 4.2 Understand the importance of sustainability } \\
\text { rating system in the industry } \\
\text { 4.3 Analyze the pros and cons of current } \\
\text { sustainability rating systems }\end{array}$ & $\begin{array}{l}\text { Cognitive } \\
\text { Cognitive } \\
\text { Cognitive }\end{array}$ \\
\hline $\begin{array}{l}\text { 5. Contemplating the } \\
\text { future direction and } \\
\text { application }\end{array}$ & $\begin{array}{l}\text { 5.1 Identify the future direction of sustainability } \\
\text { 5.2 Recognize the possible integration to other } \\
\text { industries, disciplines, etc } \\
\text { 5.3 Have more active participations in the industry } \\
\text { for sustainable construction }\end{array}$ & $\begin{array}{l}\text { Cognitive } \\
\text { Cognitive } \\
\text { Affective }\end{array}$ \\
\hline
\end{tabular}

\section{Choosing Learning Topics}

In choosing learning topics, two major rules are employed as selection criteria: the learning topics should be 1) related to the learning goals and 2) based on the learners' learning (activities). The final learning topics consist of four learning topics and eighteen sub-topics as shown in Table 6.

Table 6. Selection of Learning Topics for Sustainable Construction Course

\begin{tabular}{|l|l|l|}
\hline Learning Topics & Sub-topics & Related Objective \\
\hline $\begin{array}{l}\text { Background knowledge of } \\
\text { 'sustainability' }\end{array}$ & $\begin{array}{l}\text { Definition and significance of } \\
\text { sustainability }\end{array}$ & $1.1 / 1.2 / 1.4$ \\
& $\bullet \quad$ Historical background & 1.3 \\
\hline
\end{tabular}




\begin{tabular}{|c|c|c|}
\hline & $\begin{array}{l}\text { - Theoretical approach of sustainability } \\
\text { - Sustainable issues in social } \\
\text { background (Environmental issues) }\end{array}$ & $\begin{array}{l}1.2 / 1.4 \\
1.2 / 1.3\end{array}$ \\
\hline $\begin{array}{l}\text { Sustainability in } \\
\text { Construction }\end{array}$ & 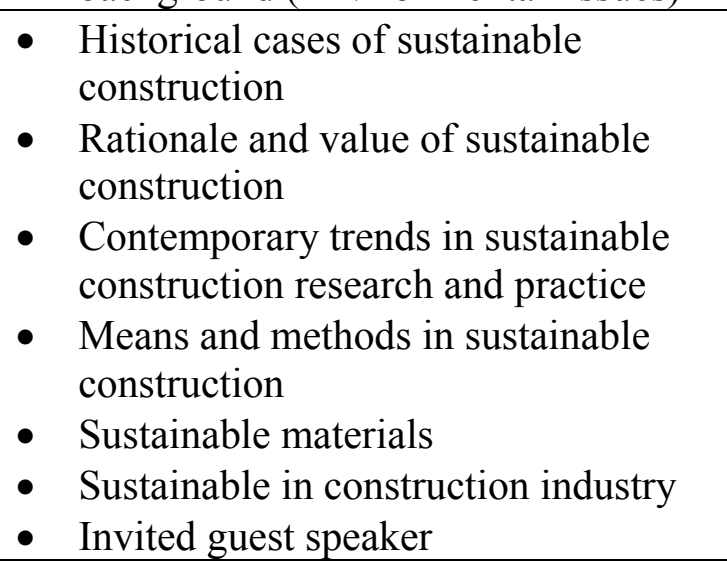 & $\begin{array}{l}1.3 / 2.1 \\
2.2 \\
2.1 / 2.4 \\
2.1 \\
3.1 \\
2.1 \\
2.1 / 2.3 / 2.4 / 5.1\end{array}$ \\
\hline $\begin{array}{l}\text { Analytic assessment for } \\
\text { sustainable construction }\end{array}$ & $\begin{array}{l}\text { - Critical analysis of current sustainable } \\
\text { construction cases } \\
\text { - Sustainable rating systems (LEED, } \\
\text { etc) } \\
\text { - Assessment strategies for sustainable } \\
\text { construction }\end{array}$ & $\begin{array}{l}2.3 / 3.5 / 5.2 \\
4.1 / 4.2 / 4.3 \\
4.1 / 4.2 / 4.3 / 5.1\end{array}$ \\
\hline $\begin{array}{l}\text { Implementation for } \\
\text { sustainable construction }\end{array}$ & $\begin{array}{l}\text { - Sustainable design practice } \\
\text { - Case study related to sustainable } \\
\text { construction } \\
\text { - Community practice for sustainable } \\
\text { construction } \\
\text { - Internship or practicum field trip }\end{array}$ & $\begin{array}{l}2.1 / 3.2 \\
2.1 / 3.2 \\
3.2 / 3.3 / 3.4 / 3.5 / 3.6 / 3.7 \\
\\
2.1 / 3.1 / 3.2 / 3.3 / 3.4 / 3.5 / \\
3.6 / 3.7 / 5.1 / 5.2 / 5.3\end{array}$ \\
\hline
\end{tabular}

\section{Organizing Learning Topics}

The next stage is to organize learning topics and provide descriptions and instructional strategies as shown in Table 7. Major instructional strategies are 'instructor's lecture and presentation', learner's presentations', learner's research: case study', 'group work', 'field trip', 'assignment', and 'group and individual report'. The instructor's lecture and presentation are needed for quick class/assignments introduction and establishment of the basic notions. This course design especially emphasizes learner-centered instruction, collaboration through group discussion, report, and presentation.

Table 7. Organizing Learning Topics and Description

\begin{tabular}{|l|ll|l|}
\hline \multicolumn{1}{|c|}{ Learning Contents } & \multicolumn{1}{|c|}{ Description } & Instructional Strategies \\
\hline 1. Class Orientation & - & Explanation for course syllabus & Instructor's lecture \& \\
& - & Introduction to assignments & presentation \\
& - & Assigning groups for activities & Continuous feedback \\
\hline
\end{tabular}




\begin{tabular}{|c|c|c|}
\hline & - Describing the field trip & \\
\hline $\begin{array}{l}\text { 2. Instructor's } \\
\text { presentation on } \\
\text { sustainable } \\
\text { construction }\end{array}$ & $\begin{array}{ll}\text { - } & \text { Explanation of environmental issues } \\
\text { - } & \text { Definition and theory of sustainable } \\
\text { construction } \\
\text { - }\end{array}$ & $\begin{array}{l}\text { Instructor's lecture } \\
\text { Assignment \# } 1 \\
\text { Group discussion \# } 1 \\
\text { Group discussion \# } 2 \\
\text { Assignment \# 2 }\end{array}$ \\
\hline $\begin{array}{l}\text { 3. Learning the current } \\
\text { sustainable } \\
\text { construction practices }\end{array}$ & $\begin{array}{ll}\text { - } & \text { Explanation of current sustainable } \\
\text { construction practice } \\
\text { - } & \text { Components of sustainable } \\
\text { construction practice } \\
\text { - Issues of sustainable construction } \\
\text { practice }\end{array}$ & $\begin{array}{l}\text { Instructor's lecture } \\
\text { Lecture \& discussion } \\
\text { Assignment \# } 3 \\
\text { Group discussion \# } 3\end{array}$ \\
\hline $\begin{array}{l}\text { 4. Learning sustainable } \\
\text { construction } \\
\text { assessment tools }\end{array}$ & 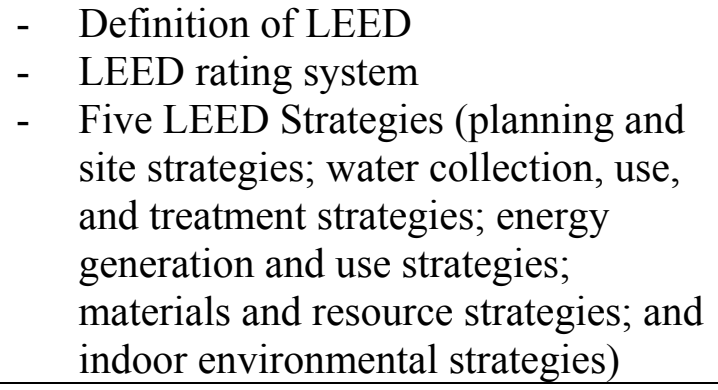 & $\begin{array}{l}\text { Instructor's lecture } \\
\text { Assignment \# } 4 \\
\text { Group presentation \# } 1\end{array}$ \\
\hline $\begin{array}{l}\text { 5. Economics of } \\
\text { sustainability }\end{array}$ & $\begin{array}{l}\text { Economic issues of sustainable } \\
\text { construction }\end{array}$ & Group discussion \# 4 \\
\hline 6. Site learning & $\begin{array}{ll}\text { - } & \text { Field trip to sustainable construction } \\
\text { site } \\
\text { - } & \text { Project description } \\
\text { - } & \text { Application of sustainable } \\
\text { construction } \\
\text { - } & \text { Issues of sustainable construction }\end{array}$ & $\begin{array}{l}\text { Assignment \# } 5 \text { Field } \\
\text { trip report }\end{array}$ \\
\hline $\begin{array}{l}\text { 7. Sustainable } \\
\text { construction case } \\
\text { study }\end{array}$ & 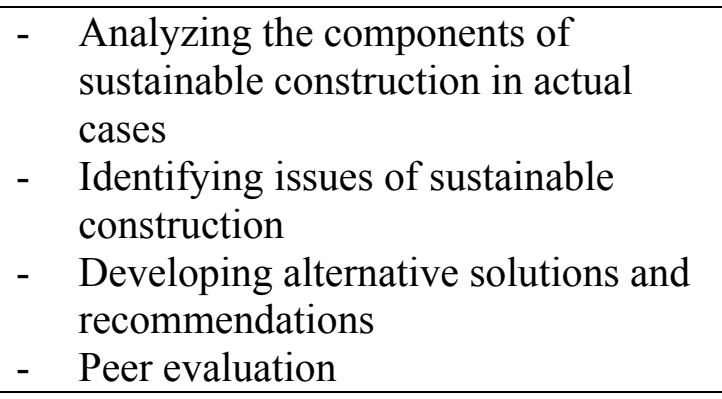 & $\begin{array}{l}\text { Project report: group } \\
\text { work } \\
\text { Group Presentation \# } 2\end{array}$ \\
\hline $\begin{array}{l}\text { 8. Future direction of } \\
\text { sustainable } \\
\text { construction }\end{array}$ & $\begin{array}{ll}- & \text { Guest speaker } \\
- & \text { Diffusion of sustainable construction } \\
\text { - } & \text { Future directions of sustainable } \\
& \text { construction }\end{array}$ & $\begin{array}{l}\text { Assignment \# } 6 \\
\text { Group discussion } \\
\text { Group discussion }\end{array}$ \\
\hline
\end{tabular}

The assessment plan in this course was organized utilizing the philosophy of constructivism as a base. In this educational trend, assessments emerge from learner-centered instruction and evaluation. In other words, many education experts and teachers are focusing on assessment of 
the whole learning process $[17,18,22]$. The assessment plan is strongly associated with grade issues. Moreover, the assessment plan is presented for each assessment category in Table 8 .

Table 8. Assessment Contents for Sustainable Construction Course

\begin{tabular}{|c|c|}
\hline Assessment Contents & $\begin{array}{c}\text { Percentage } \\
(\%)\end{array}$ \\
\hline $\begin{array}{l}\text { 1. Assignments } \\
\text { - Summarizing five direct sustainable construction definitions } \\
\text { - Reviewing five different journal articles related to sustainable construction } \\
\text { - Summarizing components of sustainable construction practices } \\
\text { - Comparing five different LEED certification strategies } \\
\text { - Developing field trip report } \\
\text { - Predicting future direction of sustainable construction }\end{array}$ & $\begin{array}{c}40 \% \\
5 \% \\
5 \% \\
5 \% \\
5 \% \\
10 \% \\
10 \%\end{array}$ \\
\hline $\begin{array}{l}\text { 2. Presentations } \\
\text { - Group presentation on the five LEED strategies from a LEED silver } \\
\text { certified building } \\
\text { - Group presentation for possible sustainable construction strategies for a } \\
\text { newly constructed building }\end{array}$ & $\begin{array}{l}20 \% \\
10 \% \\
10 \%\end{array}$ \\
\hline 3. Project Report & $30 \%$ \\
\hline $\begin{array}{l}\text { 4. } \\
\text { Participation } \\
\text { - In class activities and field trip } \\
\text { - Group discussion }\end{array}$ & $10 \%$ \\
\hline
\end{tabular}

\section{Improvement Stage for Course Development}

In order to improve the developed course, the evaluation stage with the expert group will be performed. The expert group for evaluating the developed course consists of two sustainable experts and two course development experts. The evaluations will be performed by the descriptive and analytic comments of the evaluators about the developed course plan ([A] A framework of design course in technology education, [B] Developing learning goals and objectives, [C] Learning topics, [D] Instructional strategies, and [E] Assessment schedule in 'Sustainable construction course'). From the comments and review, the first draft model of the course plan will be improved and modified.

\section{Summary \& Conclusion}

This research has identified the importance of sustainable construction education in construction programs; the current status of sustainable construction education courses all over the world; the purpose of pioneer sustainable construction courses in construction programs in the U.S.A.; and the industry sustainable knowledge expectancy of construction graduates. Based on the sustainable construction education needs, the authors developed the sustainable construction course through systematic course development. The course contains the syllabus and detailed description on the sustainable construction course for the undergraduate students at the construction program. The developed course will be offered to senior students in construction 
programs in order to motivate students to integrate their basic construction knowledge into sustainable knowledge and skill.

This concourse is presented with the desire that construction educators will be motivated to open the sustainable construction courses and to teach sustainable construction issues.

\section{Reference}

[1] U.S. Census, “2005 Country business pattern.” U.S. Census.

http://www.census.gov/econ/census02/naics/sector23/23.htm (accessed December 15, 2007)

[2] Kibert, C., Sustainable Construction, John Wiley \& Sons, NJ, 2005.

[3] U.S. Green Building Council, “U.S. Green Building Council.” USGBC. http://www.usgbc.org (accessed November 10, 2007)

[4] Bosch, S., and A. Pearce, "Sustainability in Public Facilities." Journal of Performance of Constructed Facilities, vol. 17, no. 1, 2003, pp. 9-18.

[5] Mager, R.F., and K.M. Beach, Developing vocational instruction, California, 1967.

[6] Randolph, W.A., and B.Z. Posner, What every manager needs to know about project management, Englewoods, New Jersey, 1988.

[7] Tyler, R.W., Basic principles of curriculum and instruction, Chicago, 1949.

[8] Finch, C. R. and Crunkilton, J. R., 1989. Curriculum Development in Vocational and Technical Education; Planning, Content, Implementation. Allyn and Bacon, INC.

[9] Kwon, H. S., and S. B. Yi., "The development of hands-on activities based production technology curriculum by objective model at the secondary school." Journal of Korea Technology Education Association, vol. 3 no. 1, 2003.

[10] Graham, P., "Building education for the next industrial revolution: teaching and learning environmental literacy for the building professions." Construction Management and Economics, vol. 18, 2000, pp. $917-928$.

[11] Mead, S.P., "Green Building: Current Status and Implications for Construction Education." Proceeding of Associate School of Construction, Fort Collins, Colorado, 2002.

[12] Woodruff. P. H., "Educating Engineers to Create a Sustainable Future." Journal of Environmental Engineering, vol. 132, no. 4, 2006, pp. 434-444.

[13] Cotgrave, A., and R. Alkhaddar, "Greening the Curricula with Construction Programs." Journal of Education in the Built Environment, vol. 1, no. 1, 2006, pp. 3-29.

[14] Chau, K. W., "Incorporation of Sustainability Concepts into a Civil Engineering Curriculum." Journal of Professional Issues in Engineering Education and Practice, Vol. 133. no. 3, 2006, pp. 188-191.

[15] Tinker, A., and R. Burt, "Greening the Construction Curriculum." International Journal of Construction Education and Research, vol. 9, no. 2, 2004, pp. 26-33.

[16] Hayles, C. S., S. E. Holdsworth, "Curriculum Change for Sustainability." Proceeding of the Built Environment Education Annual Conference, London, United Kingdom, 2006.

[17] Hayles, C. S., K. Robson, and S. E. Holdsworth, "A case study from RMIT: introducing property undergraduates to the immediate issues of housing sustainability and affordability within Australia and New Zealand."Proceeding of The PRRES Conference, Auckland, New Zealand, 2006.

[18] Murray, P. E., and A. J. Cotgrave, "Sustainability Literacy: the future paradigm for construction education." Structural Survey, vol. 25, no. 1. 2007, pp. 7-23.

[19] Choi, Y., The study of technology education, Hyungsyul Publication, Seoul, 2005.

[20] Ahn. Y. H., and A.R. Pearce, "Green Construction Experiences, Expectations, and Perceptions." Journal of Green Building, vol. 2, no. 3, 2007, pp. $106-122$.

[21] Bloom, B. S. \& David, R. K. Taxonomy of Education Objectives: The Classification of Education Goals, by a committee of college and university examiners. New York, Longmans, Green, 1956

[22] International Technology Education Association, Standards for Technological Literacy: Content for the study of technology, Reston, 2000. 